\title{
Biology of pancreatic stellate cells-more than just pancreatic cancer
}

\author{
Pawel E. Ferdek ${ }^{1}$ - Monika A. Jakubowska ${ }^{1}$
}

Received: 10 February 2017 / Revised: 13 March 2017 / Accepted: 16 March 2017 /Published online: 5 April 2017

(C) The Author(s) 2017. This article is published with open access at Springerlink.com

\begin{abstract}
Pancreatic stellate cells, normally quiescent, are capable of remarkable transition into their activated myofibroblast-like phenotype. It is now commonly accepted that these cells play a pivotal role in the desmoplastic reaction present in severe pancreatic disorders. In recent years, enormous scientific effort has been devoted to understanding their roles in pancreatic cancer, which continues to remain one of the most deadly diseases. Therefore, it is not surprising that considerably less attention has been given to studying physiological functions of pancreatic stellate cells. Here, we review recent advances not only in the field of pancreatic stellate cell pathophysiology but also emphasise their roles in physiological processes.
\end{abstract}

Keywords Pancreatic stellate cells · Fibrosis · Pancreatitis . Pancreatic cancer $\cdot$ Calcium $\cdot$ Myofibroblasts

\section{Introduction}

The diffuse stellate cell system is composed of star shaped cells woven into various mammalian organs including, but not limited to, the liver, pancreas or kidney [26, 32, 136]. Despite some tissue-specific differences, so-called quiescent

Pawel E. Ferdek and Monika A. Jakubowska contributed equally to this review.

Pawel E. Ferdek

p.e.ferdek@gmail.com; ferdekpe@cardiff.ac.uk

Monika A. Jakubowska

monika.a.jakubowsk@gmail.com; jakubowskam1 @ cardiff.ac.uk

1 Medical Research Council Group, Cardiff School of Biosciences, Cardiff University, Cardiff, Wales CF10 3AX, UK stellate cells are uniformly characterised by their ability to store retinoids - vitamin A and its analogues - mainly in a form of lipid droplets scattered in the cytosol [2, 34, 136]. These lipid-packed cells normally possess only a limited capacity to proliferate and migrate within the parenchymal tissue and show no detectable expression of $\alpha$-smooth muscle actin $(\alpha$-SMA) [2, 32]. Importantly, loss of retinoid droplets, along with increased expression of $\alpha$-SMA, is a concomitant of stellate cell transition to an activated myofibroblast-like phenotype [26] in response to inflammatory or carcinogenic processes $[5,8,122]$. As a result, activated stellate cells not only become capable of intensive proliferation and migration, but also get heavily involved in the extracellular matrix (ECM) protein turnover, contributing towards tissue remodelling [5]. However, continued tissue injury may interfere with the normal healing processes, leading to an extended presence of activated stellate cells and resulting in excessive tissue scarring [113]. Interestingly, this may impact not only on physiological functions of the affected tissue but also on its biomechanical properties [101]. For example, stellate cell-mediated fibrosis of the vocal folds could impair the normal tissue flexibility required for emission of voice [35], a problem not uncommon for singers or broadcast personnel.

In the pancreas, pancreatic stellate cells (PSCs) build up only about 4-7\% of the organ [2] and, in contrast to the more abundant acinar cells or islets, neither secrete digestive enzymes nor hormones. However, in chronic pancreatitis and pancreatic ductal adenocarcinoma (PDAC), it is the activated PSCs that deposit collagen fibres and contribute to the development of pancreatic fibrosis $[5,26]$. Activated PSCs have recently been the focus of multiple studies and continue to attract a lot of interest, especially in relation to pancreatic cancer, often perceived as a death sentence. PSCs have not only been shown to form a dense fibrotic stroma and interact with cancer cells, but may also be capable of travelling within 
the body to colonise distant metastases [122, 131]. Despite this substantial progress made in the past two decades, to date surprisingly little is known about the physiological roles of quiescent PSCs in the healthy tissue. Here, we highlight the advances in the PSC field, predominantly in respect of the function of these cells in the normal tissue, their roles in acute and chronic pancreatitis as well as in pancreatic cancer. Also, we would like to draw particular attention to the involvement of ion channels in PSC biology.

\section{Discovery}

Although the discovery of hepatic stellate cells (HSCs) is commonly attributed to Carl von Kupffer [32], who also introduced the term "stellate cells" (1876), more than one research group contributed to the identification of PSCs. The first documented observation most likely describing what we know today as PSCs was published by Watari et al. in 1982 [126]. In the pancreata isolated from mice fed with retinoids, the authors noticed vitamin A-loaded cells either scattered randomly in the tissue or located in the vicinity of the blood capillaries [126]. Even though not explicitly referred to as PSCs, periacinar fibroblast-like cells were first isolated and cultured in 1997 by Saotome et al. [99]. However, most of the credit for identification of PSCs has been given to two independent research papers accepted for publication a year later [2, 6]. Both those studies, by Apte et al. and Bachem et al. $[2,6]$, applied density gradient centrifugation to isolate quiescent rat PSCs, a procedure previously used for purification of HSCs $[33,34,66]$. Bachem et al. also introduced the outgrowth method that yielded activated PSCs, neatly grown out of small tissue blocks of either rat or human origin [6]. PSC research has been further aided by the development of an immortalised rat cell line in 2004 [113]. These studies triggered a sudden outburst of interest in the previously overlooked cells that continues until today.

\section{Pancreatic versus hepatic stellate cells}

PSCs are often compared to HSCs due to their similar morphological and functional features. In principle, both cell types are capable of expressing the same protein markers such as desmin and glial fibrillary acidic protein (GFAP); however, the exact expression levels vary markedly between different species [36, 104, 132, 136] or even in different cells of the same individual [45]. The gene expression profiles of PSCs and HSCs show a high degree of similarity, but differ from fibroblasts [14]. In contrast to stellate cells in their activated phenotype, fibroblasts are generally negative for desmin and $\alpha$-SMA and also show a less pronounced synthesis of ECM proteins [7].
Despite clear similarities, some organ-specific differences in expression patterns exist between PSCs and HSCs. To name a few, PSCs are characterised by higher levels of $\alpha 7$ integrin, hypoxia inducible factor $1 \alpha$ subunit (HIF1 $\alpha$ ), and cytoskeletal components [14]. Therefore, findings related to one cell type cannot be ad hoc transferred to another.

Since PSCs express both mesenchymal and ectodermal markers, their origin has been the subject of debate. A similar discussion has been finally settled for HSCs owing to a study that pointed towards their mesenchymal origin [16]. This is also likely to be true for PSCs, but firm experimental evidence is still lacking. Nevertheless, at least a subpopulation of PSCs in the normal and inflamed pancreas has been shown to be derived from the bone marrow progenitors $[73,102,114]$.

\section{Quiescent pancreatic stellate cells}

In their quiescent phenotype, PSCs appear stagnant and almost redundant and currently very little is known about their physiological functions. These cells normally form a threedimensional network that runs in between pancreatic lobules (Fig. 1) adjacent to the ducts and blood capillaries [2]. Interestingly, it remains unexplored whether normal functioning of PSCs depends on maintaining this characteristic network-like structure. The presence of stellate cells has also been reported in islets of Langerhans, predominantly responsible for the release of insulin and glucagon [134]. It was suggested that these particular cells may be a subpopulation of conventional PSCs [134] that play a role in islet fibrosis related to severe cases of diabetes [51].

Quiescent PSCs are most likely responsible for the turnover of ECM components since they secrete metalloproteinases (MMP) including MMP-2, MMP-9, and MMP-13, as well as their inhibitors [95]. That, however, is rather unlikely to exhaust the full array of physiological functions of quiescent PSCs. Other roles for these cells have been postulated, such as the cholecystokinin (CCK)-elicited release of acetylcholine (ACh), which in turn stimulates acinar secretion [96]. Cultured human PSCs were shown to express ACh synthesising systems and CCK receptors [96]. However, experiments on isolated pancreatic lobules provided no evidence for the presence of CCK receptors in mouse quiescent PSCs; also no $\mathrm{Ca}^{2+}$ responses were detected in those cells upon CCK stimulation [40]. Furthermore, since expression of toll-like receptors (TLR) have been found in isolated rat PSCs, one might speculate that stellate cells could play a role in innate immunity by phagocytosis of exo- and endogenous antigens [81]. This notion is further supported by a different study, which demonstrated phagocytic activity in PSCs as well as the presence of the scavenger receptor CD36 [110], also known to be expressed by monocytes/macrophages [89]. Interestingly, in HSCs, this receptor is fully functional and 


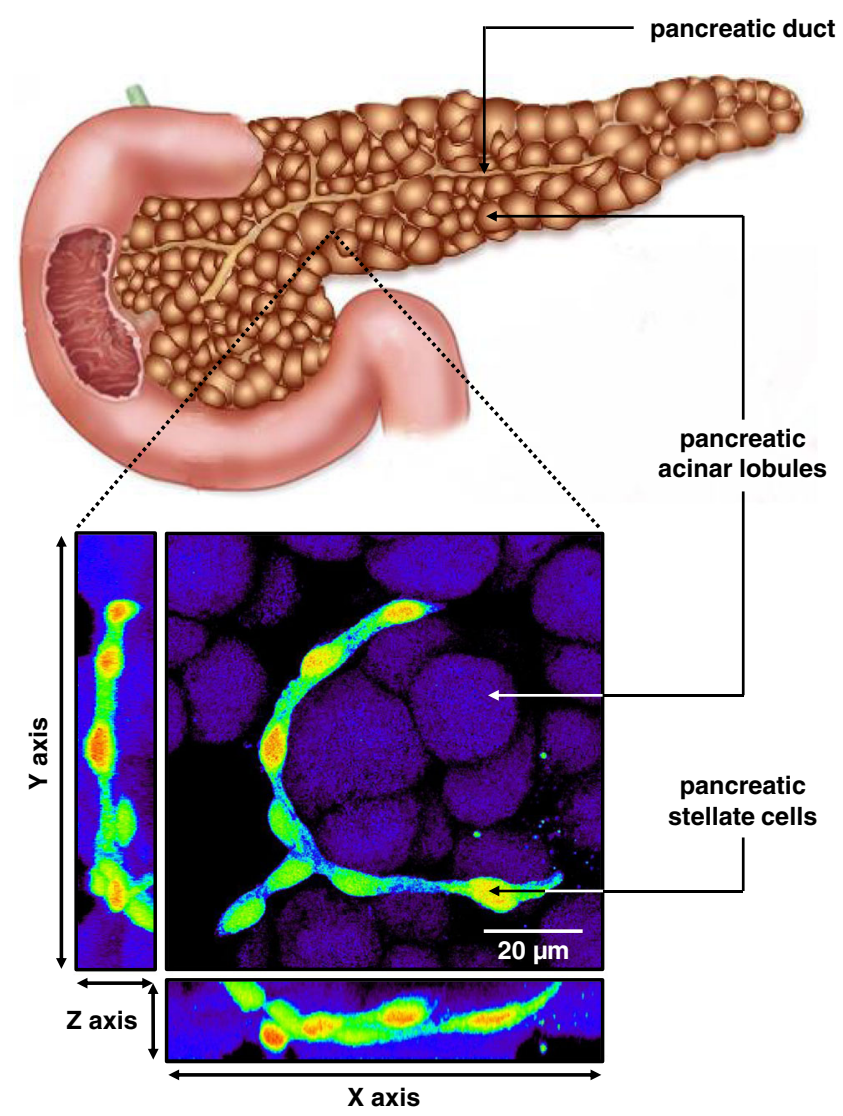

Fig. 1 Schematic illustration of the pancreas. The exocrine part of the organ predominantly consists of acinar lobules. Pancreatic stellate cells (shown in bright green-yellow-red pseudocolours, lower panel) form a three-dimensional network in between those lobules (dark purple)

capable of binding oxidised low density lipoprotein, which is associated with acquisition of the activated phenotype [63, 106]. This may suggest some similarities of stellate cells to phagocytic immune cells.

Quiescent stellate cells contain retinoids (Fig. 2), predominantly as retinyl palmitate cytosolic droplets [11, 48], whose formation is likely to be dependent on intracellular albumin [65]. In the adult body, up to $80 \%$ of dietary retinoids is stored in the liver [12], in which HSCs remain a fraction 60-times enriched in vitamin A analogues as compared to the liver parenchymal cells [12]. The levels of retinoids contained in PSCs are substantially lower and more variable than in HSCs [55]. The exact role of retinoids in PSCs has not been investigated in great detail. It is well known, however, that retinoid family members are vital for the maintenance of tissue homeostasis by controlling cell growth, differentiation as well as apoptotic cell death $[9,98,118]$; whereas by regulating embryonic signalling pathways $[20,97]$ they govern "stemness" of cancer cells $[9,133]$. During early days of development in utero, the gradient of retinoid distribution may serve either as an instructive or permissive signal for embryogenesis [24]. Retinoic acid (RA) is required for normal development of the embryonic pancreas [24, 97], as shown in the frog [18],

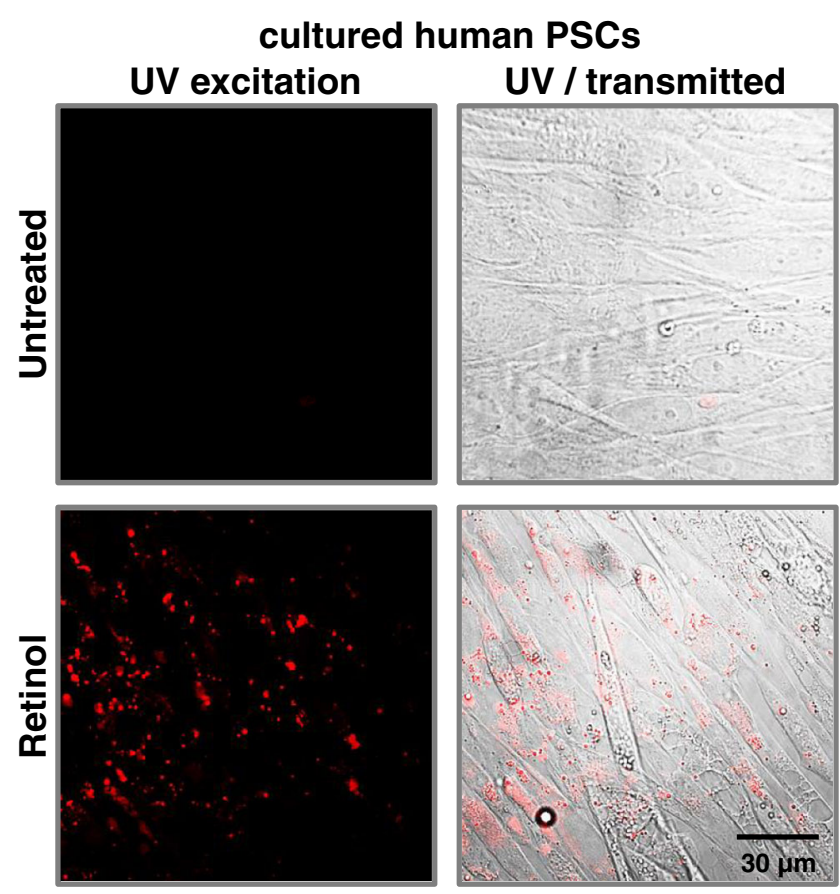

Fig. 2 Pancreatic stellate cells have the capacity to store retinoids. Cultured human PSCs quickly become activated and lose most of their stored retinol (upper panel). In the presence of $100 \mu \mathrm{M}$ retinol $(24 \mathrm{~h}$ treatment), lipid vesicles appear in the cytosol of PSCs (lower panel, red pattern), which is revealed by excitation with UV light

zebra fish [53], and mouse models [74]. Further, the influence of retinoids on the organogenesis of the pancreas is related to their stimulatory effect on differentiation of endocrine and duct cells [53, 118], and apoptosis of acinar cells [118]. In adult pancreas, RA isomer 9-cis-retinoic acid (9cRA) has been shown to act as a pancreas-specific autacoid [62]. As it has been demonstrated, 9cRA is generated in situ in the pancreas, where it briefly attenuates glucose-stimulated insulin secretion [62].

Retinoids may facilitate maintenance of the quiescent state of PSCs, especially given that retinol and its metabolites have been shown to inhibit expression of $\alpha$-SMA and decrease activation of relevant signalling pathways [82]. All-transretinoic acid (ATRA) has been proposed to trigger restoration of mechanical quiescence of PSCs [19, 100], suppress their capacity to remodel the extracellular matrix [100] and thus inhibit cancer cell invasion [19].

\section{Activated pancreatic stellate cells}

The pathophysiological roles of PSCs become apparent in healing injuries caused by inflammation. Despite having certain stem cell characteristics [26], PSCs probably cannot directly replace or regenerate damaged cells; instead they substitute lost cellular components with fibrotic tissue. This "quick fix" is initially crucial for restoring organ integrity. 
However, an extended presence of activated PSCs may transform into a pathological process leading to the deposition of excessive amounts of ECM proteins and thus permanent scarring of the pancreas accompanied by loss of cellular components.

Damage to the pancreatic tissue triggers activation of PSCs, in response to inflammatory mediators $[1,83]$, alcohol metabolites [4] or growth factors such as the platelet-derived growth factor (PDGF) $[3,105]$ or transforming growth factors TGF- $\alpha$ and TGF- $\beta[3,116,121]$. These activating factors are present in the inflamed pancreas and are secreted by infiltrating cells (e.g. macrophages), platelets, endothelial cells or pancreatic acinar cells [75]. Also, transformed cells in pancreatic cancer are a source of agents triggering activation of PSCs [26]. Importantly, PSCs themselves may be able to secrete certain growth factors (e.g. PDGF) or cytokines and thus facilitate their activation in auto- or paracrine manner [3, 70, 105, 109].

The process of PSC phenotype transition is associated with clear morphological and functional changes. Its most widely accepted features are loss of retinoid droplets from the cytosol and increased expression of $\alpha$-SMA (Fig. 3) [2, 6]. Activated PSCs assume a spindle-like shape in vitro, actively proliferate and migrate as well as show an increase in production of collagen type I and III, laminin and fibronectin [6].

\section{mouse pancreas}
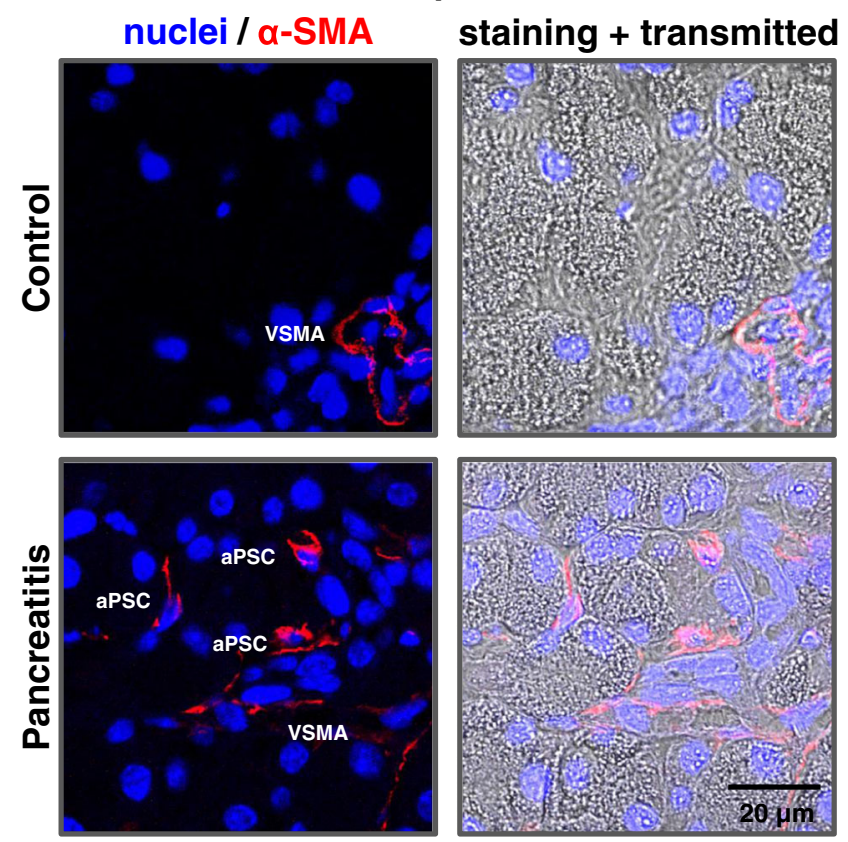

Fig. 3 Expression of $\alpha$-smooth muscle actin ( $\alpha$-SMA), and thus the number of activated PSCs (aPSCs), increases as a result of tissue inflammation. In the healthy mouse pancreas (upper panel) $\alpha$-SMApositive staining (red) is only present in the vascular smooth muscle cells in the blood vessels and is labelled as vascular smooth muscle actin (VSMA). Induction of pancreatitis (by ethanol and fatty acids) leads to a sudden appearance of $\alpha$-SMA-positive cells —aPSCs — scattered within the parenchymal tissue
Furthermore, they also secrete neutrophil chemotactic factor IL-8 and macrophage chemoattractant protein-1 (MCP-1) [1, 117]; as well as express intracellular adhesion molecule-1 (ICAM-1) [77]. This suggests that activated PSCs may be involved in exacerbating inflammation in the pancreas by recruitment of inflammatory cells. The presence of $\alpha$-SMA along with endothelin-1 gives PSCs elasticity and the potential for contractions [79]. Given the periductal and perivascular localisation of these cells, it has been speculated that the contractility traits of activated PSCs may contribute to the regulation of vascular and ductal tones [75]. Also, PSCs in their myofibroblast-like phenotype have been implicated in the remodelling and further stiffening of pathological fibrosis in response to external mechanical stimuli [19]. Processes of PSC activation may thus affect the biomechanical tissue homeostasis.

A detailed clarification of the mechanisms controlling phenotype transition of PSCs probably represents one of the most important challenges in the stellate cell field in the coming years. Among the identified candidates implicated in this process are the mitogen-activated protein kinase (MAPK) family members [60,78], NF-kB [77, 109] and downregulation of peroxisome proliferator-activator receptor $\gamma(\operatorname{PPAR}-\gamma)[61$, 76]. Signalling pathways associated with the phenotype transition have been reviewed in more detail in previous publications $[59,75]$.

\section{Ion channel biology of pancreatic stellate cells}

The importance of $\mathrm{Ca}^{2+}$ signalling in the exocrine pancreas is well illustrated by the fact that secretion of digestive enzymes by acinar cells is controlled by intracellular $\mathrm{Ca}^{2+}$ oscillations $[91,93]$. What is more, dysregulated $\mathrm{Ca}^{2+}$ signals underlie the necrotising diseases of the pancreas: acute and chronic pancreatitis $[38,92]$. Although $\mathrm{Ca}^{2+}$ signalling events have been extensively investigated in pancreatic acinar cells, ion fluxes in PSCs and their consequences have been a subject of only a very limited number of studies. However, as discussed below, recent evidence revealed that the physiology of PSCs is also regulated by intracellular $\mathrm{Ca}^{2+}$ signalling and further insights into these processes may shed new light on the roles of quiescent PSCs and the mechanisms of their phenotype transition.

The first attempt to characterise the differences in $\mathrm{Ca}^{2+}$ signals between quiescent and activated PSCs has been made by Won et al. [128]. Their work elegantly demonstrated that while activated PSCs responded to agonists of proteaseactivated receptor 1 or 2 (thrombin and trypsin, respectively) with transient elevations of intracellular $\mathrm{Ca}^{2+}$, these responses were completely absent in quiescent PSCs [128]. Importantly, the authors also showed that angiotensin and bradykinin were potent inducers of $\mathrm{Ca}^{2+}$ signals in both quiescent and activated PSCs [128]. A later study by Gryshchenko et al. revealed that 
bradykinin receptor 2 was responsible for the bradykinininduced intracellular $\mathrm{Ca}^{2+}$ elevation in these cells [40]. Expression of this receptor has been shown both in paraffinembedded mouse pancreatic tissue slices $[30,58]$ and in cultured human PSCs [30]. Bradykinin responses could be used to distinguish PSCs from acinar cells (unresponsive to bradykinin) and thus may be a useful physiological marker of the stellate phenotype in the pancreatic tissue [30,58].

Several types of purinergic receptors $\mathrm{P} 2 \mathrm{X}$ and $\mathrm{P} 2 \mathrm{Y}$ have been found in PSCs $[15,49,68]$ and $\mathrm{Ca}^{2+}$ responses to ATP, UTP and UDP have been recorded in these cells [49]. Won et al. demonstrated that activated PSCs were more sensitive to ATP than the quiescent cells [128]. This is interesting, especially in light of the findings of Haanes et al., who showed that high ATP concentrations induced cell death in normal PSCs but not in cells lacking the functional purinergic receptor P2X7 [42]. The authors concluded that the latter receptor may act as a death receptor when exposed to high doses of ATP [42]. It is therefore likely that ATP could contribute to removal of activated PSCs. Also, the P2X7 receptor has been suggested to be involved in regulation of PSC proliferation, since mice lacking this receptor had substantially fewer PSCs than normal mice; and those cells proliferated more slowly in culture than normal cells [42]. Of note is also the observation that low ATP levels had a stimulatory effect on proliferation of PSCs [42].

Zhang et al. reported increased expression of the transient receptor potential vanilloid 4 (TRPV4) channel in PSCs isolated from rats fed with high-fat and alcohol diet for 6 weeks [135]. Despite the mild phenotype of chronic pancreatitis (as shown by histological techniques), increased and sustained intracellular $\mathrm{Ca}^{2+}$ mobilisation was observed. The authors concluded that TRPV4 is a functional ion channel in PSCs, which mediates responses to metabolites of alcohol and fatty acids [135].

A very recent study found a potentially important link between $\mathrm{Ca}^{2+}$ fluxes and pancreatic cancer desmoplasia, which contributes to increased physical pressure in the neoplastic tissue. This high pressure led to activation of mouse PSCs, a process mediated by $\mathrm{Ca}^{2+}$ influx through the transient receptor potential canonical 1 (TRPC1) channels; and thus the authors suggested a link between TRPC1 and pressure sensing in PSCs [29].

The importance of ion channels has also been illustrated by another study that not only provided the evidence for functional expression of the $\mathrm{Ca}^{2+}$ sensitive $\mathrm{K}^{+}$channel of intermediate conductance, $\mathrm{K}_{\mathrm{Ca}} 3.1$, and the TRPC 3 channel in human PSCs, but also demonstrated their role in PSC migration [115]. The distribution patterns of these two channel proteins in the plasma membrane of human PSCs revealed a very high degree of colocalisation [115]. The authors postulated cooperation between the two channels, which was based on the fact that $\mathrm{Ca}^{2+}$ responses in PSCs, induced by PDGF, were reduced by pharmacological inhibition of $\mathrm{K}_{\mathrm{Ca}} 3.1$ channels and completely abolished by the knockdown of TRPC3 [115]. Both inhibition of $\mathrm{K}_{\mathrm{Ca}} 3.1$ and loss of TRPC 3 channels substantially decreased PSC migration [115]. Given that the inhibition of $\mathrm{Ca}^{2+}$ channels has already been demonstrated to be beneficial in acute pancreatitis [37, 127], analogous strategies could be employed in novel therapeutic approaches against chronic pancreatitis and pancreatic cancer, targeting ion channels that drive PSC migration and proliferation.

In the study of Kemeny et al. [64], myofibroblasts have been isolated from different tissues of the human gastrointestinal tract and showed remarkable similarities in the expression patters of $\alpha$-SMA, desmin, vimentin and cytokeratin to PSCs. Interestingly, human gastric myofibroblasts were demonstrated to express all three isoforms of $\mathrm{Na}^{+} / \mathrm{Ca}^{2+}$ exchanger (NCX), which was attributed to the regulation of $\mathrm{Ca}^{2+}$ homeostasis in these cells as well as migration and proliferation [64].

Finally, experiments on mouse pancreatic lobules demonstrated that $\mathrm{Ca}^{2+}$ responses, induced in PSCs by both physiological and pathophysiological stimuli, do not propagate to the adjacent acinar cells [30, 40, 58]. Therefore, gap junctions, well known for allowing communication and signal propagation between acinar cells $[56,57]$, are unlikely to exist between acinar cells and PSCs [41].

\section{Pancreatic cancer}

Pancreatic cancer affects almost 340,000 people worldwide annually and is highly resistant to chemotherapy, which results in a devastating prognosis for the patients: the median life expectancy of about 6 months post diagnosis [120] and the 5-year survival rate below 5\% [124]. Infamously known as "partners in crime" [122], PSCs have recently been in the spotlight owing to their involvement in pancreatic cancer aetiology. Importantly, they have been postulated not only to contribute to the development of solid pancreatic tumours [54, 112], of which PDAC is the most common [50], but also to facilitate spreading of the disease by supporting formation of the secondary tumours (metastases) in the distant locations $[43,107,122,131]$. In addition, a recent study has proposed that PSCs may be mediators of pain in pancreatic cancer [44]. Of note is that also somewhat conflicting evidence exists in the literature, whereby depletion of $\alpha$-SMApositive myofibroblasts and thus reduced desmoplastic reaction in mouse models of PDAC, resulted in adverse outcomes, including impaired immune response and decreased survival [86].

Associated with pancreatic cancer, fibrotic stroma comprises PSCs and the products of their secretion, and may account for even up to $80 \%$ of the tumour mass [27]. A complicated network of interactions between cancer cells and PSCs has been shown to perpetuate the desmoplastic reaction $[5,8$, 107], in which the growth of the fibrotic tissue is induced by a primary distortion in the organ [5]. This leads to the formation 
of the collagen-rich fibrotic microenvironment, which tightly surrounds the malignant cells $[8,107]$ and thus may restrict blood flow, availability of oxygen, as well as limit inflammatory infiltration [28] and the delivery of chemotherapeutic agents [21, 108]. Notably, the cross-talks between cancer cells and PSCs may result in further remodelling of the stromal microenvironment via activity of MMP-2. MMP-2-mediated degradation of the stromal proteins promotes invasiveness and tumourigenicity of cancer cells, as was shown by assessment of cancer cell migration or formation of xenograft tumours in an immunodeficient mouse host [107]. The extracellular matrix may also resemble a reservoir of sequestrated mediators of inflammation released upon tissue stress or injury [103] as happens in diseases of the pancreas: pancreatitis and pancreatic cancer [52, 103]. The MMP-family enzymes have been implicated in inflammatory mechanisms, wherein they serve as damage-associated molecular patterns (DAMPs) [103].

Poor oxygenation (hypoxia) and limited nutrient availability are the hallmarks of solid tumours [39], including PDAC. The hypoxic stromal environment provides a selective pressure for the expansion of mutant cells of abnormal signalling and proliferative capacity. This may translate into tumour resistance to therapeutic approaches [39], including radiation [25]. PSCs have been shown to radioprotect the cancer cells through a $\beta 1$-integrin pathway; whereas tumours without PSCs responded to radiotherapy with a delayed growth and decreased volume compared to the tumours consisting of both cancer cells and PSCs [72].

Hypoxic conditions have also been suggested to stimulate expression of angiogenesis-regulating molecules in PSCs [80, 131]. This may play a role in spreading of the cancer cells via the blood stream or lymphatic circulation, and further progression of the cancer. Indeed, PSCs have been found to induce formation of metastases [54]. Even more importantly, a sexmismatch study elegantly proved the ability of PSCs to accompany pancreatic cancer cells to the metastatic sites [131]. In that work, orthotopic xenograft tumours in the pancreata of female mouse hosts were formed out of both human male PSCs and human female pancreatic cancer cells. This experimental setup allowed the authors to use the Y chromosome as a marker of PSCs, identified by fluorescent in situ hybridisation [131]. This confirmed the presence of exogenously introduced PSCs not only in the primary tumours in the pancreas but also in the metastases in the liver, mesentery and thoracic diaphragm [131]. Noteworthy, PSCs alone did not form tumours during a 6-month period post injection [72].

PSCs not only provide the ideal environment for the development of pancreatic cancer, protecting it against the anticancer therapies and facilitating its spreading, but also may "feed" the tumour. A recent study has shown that PSCs are critical for PDAC metabolism through the secretion of nonessential amino acids [112]. These amino acids, especially alanine, have been postulated to be an alternative source of carbon for the tricarboxylic acid cycle in the PDAC cells, that experience shortage of glucose and glutamine-derived carbon due to the surrounding stroma [112]. Interestingly, alanine secretion by PSCs is dependent on their autophagic death stimulated by the cancer cells [112]. Targeting such crosstalks between PSCs and cancer cells is an emerging novel therapeutic strategy against PDAC.

\section{Pancreatitis}

Chronic pancreatitis becomes increasingly common in the developed countries and it is generally agreed that alcohol plays a significant role in its pathogenesis [71]. Despite intensified research, still there is no effective treatment other than supportive care. Generation of reactive oxygen species and fatty acid ethyl esters, as a result of ethanol metabolism [87], induce injury of the tissue predominantly by triggering abnormal $\mathrm{Ca}^{2+}$ signals in acinar cells along with a decrease in ATP levels, followed by acinar necrosis [92, 94]. Chronic inflammation, oxidative stress and ethanol metabolites interfere with the normal healing processes [129] leading to prolonged activation of PSCs that replace acinar cells and pancreatic islets by non-cellular fibrotic tissue. This impairs both exocrine and endocrine functions of the pancreas, often resulting in malnutrition and diabetes [13]. Although not explicitly described as activated PSCs, substantial quantities of $\alpha$-SMA-positive myofibroblasts were found in alcoholic pancreatitis in human patients [22] and activated PSCs are a typical feature of animal models of chronic pancreatitis [69]. Repetitive pancreatic injury, induced by cerulein (a compound similar in action to CCK), causes deposition of collagen, and PSCs were found to be its major source $[17,85]$.

Accumulating data indicates that pancreatic fibrosis can be reversed, at least in the early stages of chronic pancreatitis [123]. It was also demonstrated that administration of RA can supress the deposition of collagen fibres [130]. However, it remains unknown if this regression of pancreatic fibrosis is dependent on transition of PSCs back to the quiescent phenotype. In fact, it is not entirely clear whether PSCs are able to revert to quiescence in vivo. Instead, they could be regenerated from a population of PSCs that have not undergone activation during injury or from a pool of progenitor cells [125]. Therefore, the phenomenon of a phenotype transition in PSCs may hold the key to our understanding of the mechanisms that drive pancreatic fibrosis and could be a viable target in anti-fibrotic therapies.

Migrating gallstones can cause bile reflux into the pancreas, which induces severe inflammation of the organ. While the bile is the most common cause of acute pancreatitis, its capacity to induce the chronic, and thus fibrotic, form of the disease is marginal $[10,88]$. In a recent study, it was reported that mouse PSCs, located in their native environment, were 
remarkably sensitive to the most common bile components [30]. Bile acids, sodium cholate and taurocholate, caused large and sustained $\mathrm{Ca}^{2+}$ signals in the cytosol of PSCs, quickly followed by necrotic death, whereas the effects of those bile acids on neighbouring acinar cells were much less prominent (Fig. 4a, b) [30]. Interestingly, PSCs appear to utilise specific mechanisms of bile acid uptake resembling those present in the liver [30]. These results are particularly surprising as, according to the prevailing dogma, the adverse effects of the bile were predominantly attributed to premature activation of digestive enzymes in acinar cells, a process triggered by excessive intracellular $\mathrm{Ca}^{2+}$ signals $[38,94]$; and, to a lesser extent, impaired ductal secretion $[47,119]$. Therefore, the recent report sheds new light on the pathogenesis of biliary pancreatitis, whereby bile acids are likely to deprive the pancreas of its repair mechanisms driving up the severity of the disease in the initial stages. At the same time, by killing PSCs, in a $\mathrm{Ca}^{2+}$ dependent manner, bile acids may not promote the development of pancreatic fibrosis in the long term. This discovery suggests that certain bile acids could even be used as therapeutic agents against fibrosis [46].

Of note is that the effects of the bile acids were further exacerbated by a pro-inflammatory mediator bradykinin
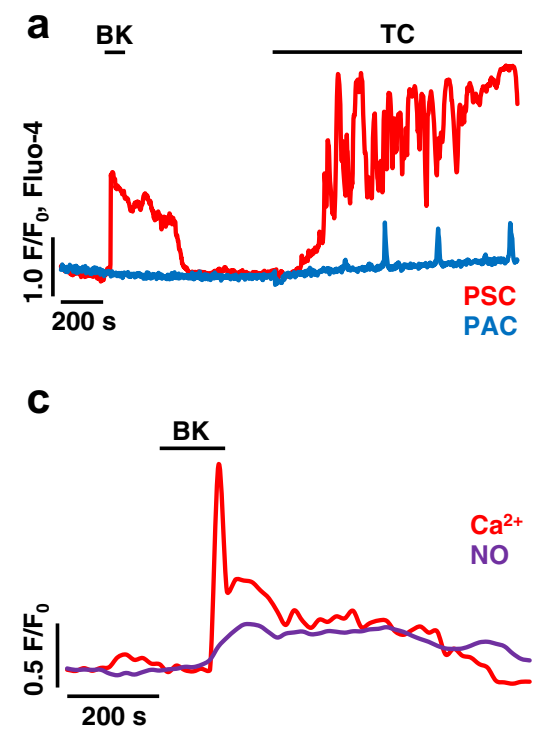

Fig. 4 Mouse pancreatic stellate cells, in their native environment of pancreatic lobules, respond to pathophysiological stimuli with intracellular $\mathrm{Ca}^{2+}$ signals as well as generation of NO. a Sample traces recorded in mouse pancreatic lobules loaded with a $\mathrm{Ca}^{2+}$-sensitive dye Fluo-4 AM. Pancreatic stellate cell (PSC, red trace) responds to $10 \mathrm{nM}$ bradykinin (BK) but pancreatic acinar cell (PAC, blue trace) does not, which confirms the stellate phenotype. The PSC subsequently responds to $5 \mathrm{mM}$ taurocholate (TC) with a large elevation of intracellular $\mathrm{Ca}^{2+}$, whereas the neighbouring PAC generates only modest $\mathrm{Ca}^{2+}$ oscillations. For more information, the reader is referred to a study by Ferdek et al. [30]. b Individual images from the recording shown in (a). The red circular regions mark the PSC that responded to bradykinin and then to taurocholate with increases in intracellular $\mathrm{Ca}^{2+}$ concentration. The blue
[30]. Injury to acinar cells causes release of enzymes stored in zymogen granules, including trypsin and kallikreins, which in turn, act on kininogens to generate kinin peptides (such as bradykinin) and further escalate the on-going inflammatory processes [41]. Indeed, increased concentrations of bradykinin elicit $\mathrm{Ca}^{2+}$ responses in PSCs, that may lead to their activation and proliferation [41].

Another study has shown that the bile acid-induced pathophysiological $\mathrm{Ca}^{2+}$ signals in PSCs, but not in acinar cells, are accompanied by nitric oxide (NO) generation [58]. In addition, bradykinin (Fig. 4c) and hydrogen peroxide (Fig. 4d) have been demonstrated not only to cause intracellular $\mathrm{Ca}^{2+}$ elevation but also a simultaneous increase in $\mathrm{NO}$ production in PSCs [58]. This indicates a link between the two signalling pathways. Expression of inducible NO synthase (NOS2) is present in PSCs, as shown by colocalisation with bradykinin receptor type 2 [58]. This is similar to a previous work that indicated NOS2-dependent production of NO in $\alpha$-SMA- and vimentin-positive pancreatic myofibroblasts that well could have been PSCs [84]. However, the actual role of NO in pancreatic diseases remains ambiguous. On the one hand, reactive oxygen/nitrogen species, such as NO, are present in the inflamed tissue and may chemically modify cellular

\section{b $\mathrm{Ca}^{2+}$ measurements in PSCs}

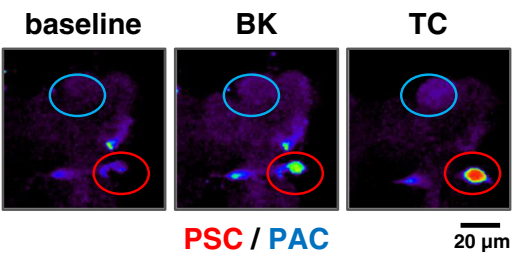

d NO measurements in PSCs

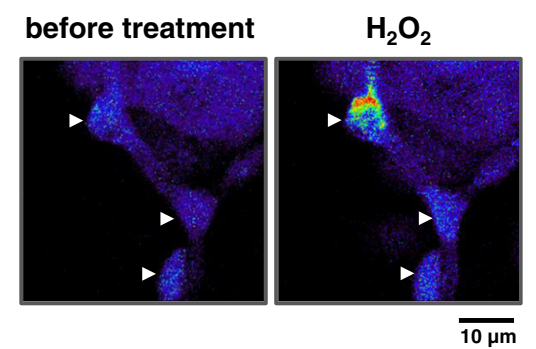

circular regions indicate the PAC that did not respond to bradykinin and produced only transient $\mathrm{Ca}^{2+}$ elevations in response to treatment with taurocholate. c Sample traces recorded in a PSC embedded in a mouse pancreatic lobule loaded with both Fura-2 $\mathrm{AM}\left(\mathrm{Ca}^{2+}\right.$-sensitive dye $)$ and DAF-2 (NO-sensitive dye). The cell responds to $20 \mathrm{nM}$ BK with an elevation of intracellular $\mathrm{Ca}^{2+}$ concentration (red trace) and a simultaneous increase in intracellular NO (purple trace). For more information, the reader is referred to a study by Jakubowska et al. [58]. d Sample images show a mouse pancreatic lobule, loaded with DAF-2, before and after treatment with $500 \mu \mathrm{M}$ hydrogen peroxide $\left(\mathrm{H}_{2} \mathrm{O}_{2}\right)$. PSCs are indicated with white arrowheads. Treatment with $\mathrm{H}_{2} \mathrm{O}_{2}$ increases intracellular NO in these cells (shown as a shift in the pseudocolour spectrum) 
components [111]. Importantly, inhibition of NO generation has been demonstrated to protect both PSCs and adjacent acinar cells against necrosis [58]. On the other hand, vascular tone and pancreatic secretion were suggested to be regulated by NO $[67,90]$, whose production was previously attributed only to endothelial cells in the pancreas [67]. Given the recent data demonstrating that PSCs can also produce NO, PSCs may contribute to the local control of circulation and secretion in the organ. Furthermore, in pancreatitis, the overproduction of NO by PSCs, in response to bile acids or bradykinin, may play a role in the increased vasodilation of ducts and blood capillaries.

\section{Concluding remarks}

Initially limited to cancer research, the field of PSCs has extended and now covers diverse aspects of cell biology. Increasingly more attention is directed towards understanding the roles of ion channels, small molecule messengers, such as $\mathrm{Ca}^{2+}$ and $\mathrm{NO}$ (Fig. 5) as well as retinoids in the physiology of PSCs. Nevertheless, still much has to be learned, especially in relation to the processes that trigger PSC phenotype transition. Given that $\mathrm{Ca}^{2+}$ plays a role in activation of other cell types such as lymphocytes [31] or mast cells [23], it would not be at all surprising if $\mathrm{Ca}^{2+}$ signals also control the process of

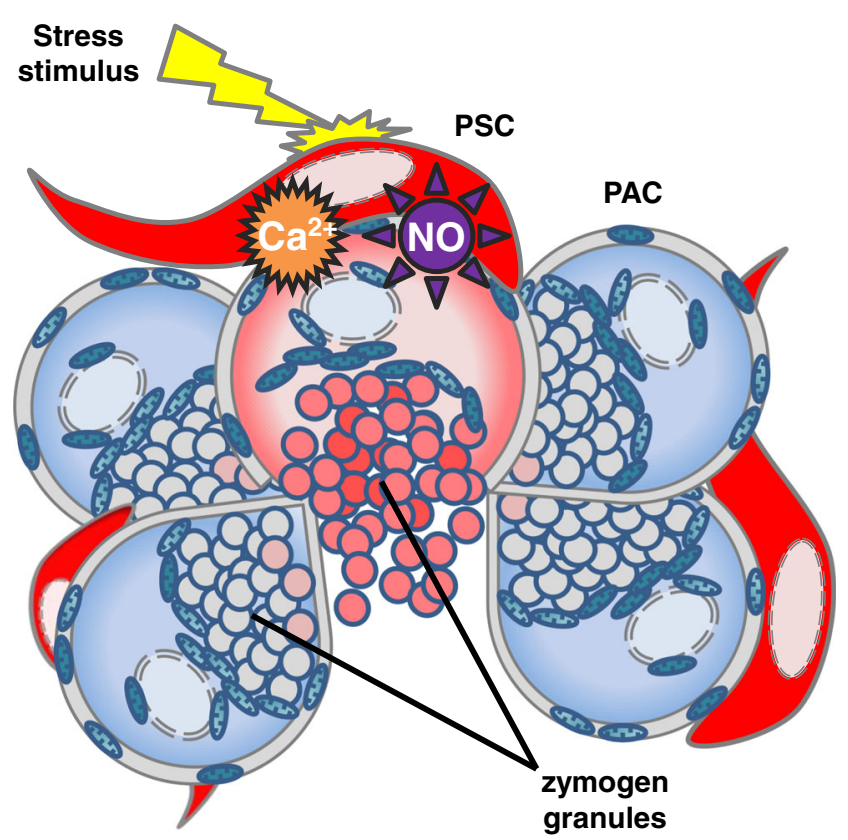

Fig. 5 Schematic illustration of a pancreatic lobule. Pathophysiological stimuli (e.g. bile acids, bradykinin, $\mathrm{H}_{2} \mathrm{O}_{2}$ ) induce stress responses in pancreatic stellate cells (PSC, red), manifested as an increase in the cytosolic $\mathrm{Ca}^{2+}$ concentration and NO generation. Stress in PSCs further escalates pathophysiological responses in adjacent pancreatic acinar cells (PAC, blue) leading to premature activation of zymogen granules, exacerbated inflammation and necrotic cell death (pink), associated with loss of the cellular content phenotype transition in PSCs. Therefore, one of the most exciting challenges in the coming years is detailed understanding of the mechanisms that govern the phenomenon of PSC activation.

Finally, it pays to remember that dysregulated physiology underlies most diseases. Therefore, intensified studies on PSC physiology and the role of $\mathrm{Ca}^{2+}$ signalling in these cells may aid the development of novel therapeutic strategies against pancreatic disorders. Particularly important would be proposing new means and approaches to inhibit PSC phenotype transition and thus supress excessive collagen deposition that leads to fibrosis. What is more, development of effective strategies to reverse PSC activation in vivo or to target specifically the population of myofibroblast-like PSCs could be of significant translational perspective.

Acknowledgements The authors were supported by a Medical Research Council Programme Grant MR/J002771/1 and by Seedcorn Grants funded by the School of Biosciences, Cardiff University. The authors would like to apologise for not being able to include all studies relevant to the pancreatic stellate cell field due to the brevity of this review.

\section{Compliance with ethical standards}

Conflict of interest The authors declare that they have no conflict of interest.

Open Access This article is distributed under the terms of the Creative Commons Attribution 4.0 International License (http:// creativecommons.org/licenses/by/4.0/), which permits unrestricted use, distribution, and reproduction in any medium, provided you give appropriate credit to the original author(s) and the source, provide a link to the Creative Commons license, and indicate if changes were made.

\section{References}

1. Andoh A, Takaya H, Saotome T, Shimada M, Hata K, Araki Y, Nakamura F, Shintani Y, Fujiyama Y, Bamba T (2000) Cytokine regulation of chemokine (IL-8, MCP-1, and RANTES) gene expression in human pancreatic periacinar myofibroblasts. Gastroenterology 119:211-219

2. Apte MV, Haber PS, Applegate TL, Norton ID, McCaughan GW, Korsten MA, Pirola RC, Wilson JS (1998) Periacinar stellate shaped cells in rat pancreas: identification, isolation, and culture. Gut 43:128-133

3. Apte MV, Haber PS, Darby SJ, Rodgers SC, McCaughan GW, Korsten MA, Pirola RC, Wilson JS (1999) Pancreatic stellate cells are activated by proinflammatory cytokines: implications for pancreatic fibrogenesis. Gut 44:534-541

4. Apte MV, Phillips PA, Fahmy RG, Darby SJ, Rodgers SC, McCaughan GW, Korsten MA, Pirola RC, Naidoo D, Wilson JS (2000) Does alcohol directly stimulate pancreatic fibrogenesis? Studies with rat pancreatic stellate cells. Gastroenterology 118: 780-794

5. Apte MV, Park S, Phillips PA, Santucci N, Goldstein D, Kumar RK, Ramm GA, Buchler M, Friess H, McCarroll JA, Keogh G, 
Merrett N, Pirola R, Wilson JS (2004) Desmoplastic reaction in pancreatic cancer: role of pancreatic stellate cells. Pancreas 29: 179-187

6. Bachem MG, Schneider E, Gross H, Weidenbach H, Schmid RM, Menke A, Siech M, Beger H, Grunert A, Adler G (1998) Identification, culture, and characterization of pancreatic stellate cells in rats and humans. Gastroenterology 115:421-432

7. Bachem MG, Schmid-Kotsas A, Siech M, Beger HG, Gress TM, Adler G (2004) Pancreatic stellate cells and their role in fibrogenesis. In: Johnson CD, Imrie CW (eds) Pancreatic disease, basic science and clinical management. Springer-Verlag, London, pp 226-239

8. Bachem MG, Schunemann M, Ramadani M, Siech M, Beger H, Buck A, Zhou S, Schmid-Kotsas A, Adler G (2005) Pancreatic carcinoma cells induce fibrosis by stimulating proliferation and matrix synthesis of stellate cells. Gastroenterology 128:907-921

9. Barnard JH, Collings JC, Whiting A, Przyborski SA, Marder TB (2009) Synthetic retinoids: structure-activity relationships. Chemistry 15:11430-11442. doi:10.1002/chem.200901952

10. Bertilsson S, Sward P, Kalaitzakis E (2015) Factors that affect disease progression after first attack of acute pancreatitis. Clin Gastroenterol Hepatol 13:1662-1669 . doi:10.1016/j.cgh.2015. $04.012 \mathbf{e} 1663$

11. Blaner WS, Hendriks HF, Brouwer A, de Leeuw AM, Knook DL, Goodman DS (1985) Retinoids, retinoid-binding proteins, and retinyl palmitate hydrolase distributions in different types of rat liver cells. J Lipid Res 26:1241-1251

12. Blomhoff R, Wake K (1991) Perisinusoidal stellate cells of the liver: important roles in retinol metabolism and fibrosis. FASEB J 5:271-277

13. Braganza JM, Lee SH, McCloy RF, McMahon MJ (2011) Chronic pancreatitis. Lancet 377:1184-1197. doi:10.1016/S01406736(10)61852-1

14. Buchholz M, Kestler HA, Holzmann K, Ellenrieder V, Schneiderhan W, Siech M, Adler G, Bachem MG, Gress TM (2005) Transcriptome analysis of human hepatic and pancreatic stellate cells: organ-specific variations of a common transcriptional phenotype. J Mol Med (Berl) 83:795-805. doi:10.1007/ s00109-005-0680-2

15. Burnstock G, Novak I (2012) Purinergic signalling in the pancreas in health and disease. J Endocrinol 213:123-141. doi:10.1530/ JOE-11-0434

16. Cassiman D, Barlow A, Vander Borght S, Libbrecht L, Pachnis V (2006) Hepatic stellate cells do not derive from the neural crest. J Hepatol 44:1098-1104. doi:10.1016/j.jhep.2005.09.023

17. Charrier AL, Brigstock DR (2010) Connective tissue growth factor production by activated pancreatic stellate cells in mouse alcoholic chronic pancreatitis. Lab Investig 90:1179-1188. doi:10. 1038/labinvest.2010.82

18. Chen Y, Pan FC, Brandes N, Afelik S, Solter M, Pieler T (2004) Retinoic acid signaling is essential for pancreas development and promotes endocrine at the expense of exocrine cell differentiation in Xenopus. Dev Biol 271:144-160

19. Chronopoulos A, Robinson B, Sarper M, Cortes E, Auernheimer V, Lachowski D, Attwood S, Garcia R, Ghassemi S, Fabry B, Del Rio HA (2016) ATRA mechanically reprograms pancreatic stellate cells to suppress matrix remodelling and inhibit cancer cell invasion. Nat Commun 7:12630. doi:10.1038/ncomms 12630

20. Colvin EK, Susanto JM, Kench JG, Ong VN, Mawson A, Pinese M, Chang DK, Rooman I, O'Toole SA, Segara D, Musgrove EA, Sutherland RL, Apte MV, Scarlett CJ, Biankin AV (2011) Retinoid signaling in pancreatic cancer, injury and regeneration. PLoS One 6:e29075

21. Dangi-Garimella S, Krantz SB, Barron MR, Shields MA, Heiferman MJ, Grippo PJ, Bentrem DJ, Munshi HG (2011) Three-dimensional collagen I promotes gemcitabine resistance in pancreatic cancer through MT1-MMP-mediated expression of
HMGA2. Cancer Res 71:1019-1028. doi:10.1158/0008-5472. CAN-10-1855

22. Detlefsen S, Sipos B, Feyerabend B, Kloppel G (2006) Fibrogenesis in alcoholic chronic pancreatitis: the role of tissue necrosis, macrophages, myofibroblasts and cytokines. Mod Pathol 19:1019-1026. doi:10.1038/modpathol.3800613

23. Di Capite J, Parekh AB (2009) CRAC channels and Ca2+ signaling in mast cells. Immunol Rev 231:45-58. doi:10.1111/j.1600065X.2009.00808.x

24. Duester G (2008) Retinoic acid synthesis and signaling during early organogenesis. Cell 134:921-931

25. Elas M, Bell R, Hleihel D, Barth ED, McFaul C, Haney CR, Bielanska J, Pustelny K, Ahn KH, Pelizzari CA, Kocherginsky M, Halpern HJ (2008) Electron paramagnetic resonance oxygen image hypoxic fraction plus radiation dose strongly correlates with tumor cure in FSa fibrosarcomas. Int J Radiat Oncol Biol Phys 71: 542-549

26. Erkan M, Adler G, Apte MV, Bachem MG, Buchholz M, Detlefsen S, Esposito I, Friess H, Gress TM, Habisch HJ, Hwang RF, Jaster R, Kleeff J, Kloppel G, Kordes C, Logsdon CD, Masamune A, Michalski CW, Oh J, Phillips PA, Pinzani M, Reiser-Erkan C, Tsukamoto H, Wilson J (2012) StellaTUM: current consensus and discussion on pancreatic stellate cell research. Gut 61:172-178. doi:10.1136/gutjnl-2011-301220

27. Erkan M, Hausmann S, Michalski CW, Fingerle AA, Dobritz M, Kleeff J, Friess H (2012) The role of stroma in pancreatic cancer: diagnostic and therapeutic implications. Nat Rev Gastroenterol Hepatol 9:454-467. doi:10.1038/nrgastro.2012.115

28. Feig C, Gopinathan A, Neesse A, Chan DS, Cook N, Tuveson DA (2012) The pancreas cancer microenvironment. Clin Cancer Res 18:4266-4276. doi:10.1158/1078-0432.CCR-11-3114

29. Fels B, Nielsen N, Schwab A (2016) Role of TRPC1 channels in pressure-mediated activation of murine pancreatic stellate cells. Eur Biophys J 45:657-670. doi:10.1007/s00249-016-1176-4

30. Ferdek PE, Jakubowska MA, Gerasimenko JV, Gerasimenko OV, Petersen OH (2016) Bile acids induce necrosis in pancreatic stellate cells dependent on calcium entry and sodium-driven bile uptake. J Physiol 594:6147-6164. doi:10.1113/JP272774

31. Feske $S$ (2007) Calcium signalling in lymphocyte activation and disease. Nat Rev Immunol 7:690-702. doi:10.1038/nri2152

32. Friedman SL (2008) Hepatic stellate cells: protean, multifunctional, and enigmatic cells of the liver. Physiol Rev 88:125-172. doi: 10.1152/physrev.00013.2007

33. Friedman SL, Roll FJ (1987) Isolation and culture of hepatic lipocytes, Kupffer cells, and sinusoidal endothelial cells by density gradient centrifugation with Stractan. Anal Biochem 161:207-218

34. Friedman SL, Rockey DC, McGuire RF, Maher JJ, Boyles JK, Yamasaki G (1992) Isolated hepatic lipocytes and Kupffer cells from normal human liver: morphological and functional characteristics in primary culture. Hepatology 15:234-243

35. Fuja TJ, Probst-Fuja MN, Titze IR (2005) Transdifferentiation of vocal-fold stellate cells and all-trans retinol-induced deactivation. Cell Tissue Res 322:417-424

36. Gard AL, White FP, Dutton GR (1985) Extra-neural glial fibrillary acidic protein (GFAP) immunoreactivity in perisinusoidal stellate cells of rat liver. J Neuroimmunol 8:359-375

37. Gerasimenko JV, Gryshchenko O, Ferdek PE, Stapleton E, Hebert TO, Bychkova S, Peng S, Begg M, Gerasimenko OV, Petersen $\mathrm{OH}$ (2013) $\mathrm{Ca}^{2+}$ release-activated $\mathrm{Ca}^{2+}$ channel blockade as a potential tool in antipancreatitis therapy. Proc Natl Acad Sci U S A 110:13186-13191. doi:10.1073/pnas.1300910110

38. Gerasimenko JV, Gerasimenko OV, Petersen OH (2014) The role of $\mathrm{Ca}^{2+}$ in the pathophysiology of pancreatitis. J Physiol 592:269280. doi:10.1113/jphysiol.2013.261784 
39. Graeber TG, Osmanian C, Jacks T, Housman DE, Koch CJ, Lowe SW, Giaccia AJ (1996) Hypoxia-mediated selection of cells with diminished apoptotic potential in solid tumours. Nature 379:88-91

40. Gryshchenko O, Gerasimenko JV, Gerasimenko OV, Petersen $\mathrm{OH}$ (2016) $\mathrm{Ca}^{2+}$ signals mediated by bradykinin type 2 receptors in normal pancreatic stellate cells can be inhibited by specific $\mathrm{Ca}^{2+}$ channel blockade. J Physiol 594:281-293. doi:10.1113/JP271468

41. Gryshchenko O, Gerasimenko JV, Gerasimenko OV, Petersen OH (2016) Calcium signalling in pancreatic stellate cells: mechanisms and potential roles. Cell Calcium 59:140-144. doi:10.1016/j.ceca. 2016.02.003

42. Haanes KA, Schwab A, Novak I (2012) The P2X7 receptor supports both life and death in fibrogenic pancreatic stellate cells. PLoS One 7:e51164. doi:10.1371/journal.pone.0051164

43. Han S, Delitto D, Zhang D, Sorenson HL, Sarosi GA, Thomas RM, Behrns KE, Wallet SM, Trevino JG, Hughes SJ (2015) Primary outgrowth cultures are a reliable source of human pancreatic stellate cells. Lab Investig 95:1331-1340

44. Han L, Ma J, Duan W, Zhang L, Yu S, Xu Q, Lei J, Li X, Wang Z, Wu Z, Huang JH, Wu E, Ma Q, Ma Z (2016) Pancreatic stellate cells contribute pancreatic cancer pain via activation of sHH signaling pathway. Oncotarget 7:18146-18158

45. Hautekeete ML, Geerts A (1997) The hepatic stellate (Ito) cell: its role in human liver disease. Virchows Arch 430:195-207

46. Hegyi P (2016) Bile as a key aetiological factor of acute but not chronic pancreatitis: a possible theory revealed. J Physiol 594: 6073-6074. doi:10.1113/JP273108

47. Hegyi P, Petersen OH (2013) The exocrine pancreas: the acinarductal tango in physiology and pathophysiology. Rev Physiol Biochem Pharmacol 165:1-30. doi:10.1007/112_2013_14

48. Hendriks HF, Verhoofstad WA, Brouwer A, de Leeuw AM, Knook DL (1985) Perisinusoidal fat-storing cells are the main vitamin A storage sites in rat liver. Exp Cell Res 160:138-149

49. Hennigs JK, Seiz O, Spiro J, Berna MJ, Baumann HJ, Klose H, Pace A (2011) Molecular basis of P2-receptor-mediated calcium signaling in activated pancreatic stellate cells. Pancreas 40:740 746. doi:10.1097/MPA.0b013e31821b5b68

50. Hezel AF, Kimmelman AC, Stanger BZ, Bardeesy N, Depinho RA (2006) Genetics and biology of pancreatic ductal adenocarcinoma. Genes Dev 20:1218-1249

51. Homo-Delarche F, Calderari S, Irminger JC, Gangnerau MN, Coulaud J, Rickenbach K, Dolz M, Halban P, Portha B, Serradas $\mathrm{P}$ (2006) Islet inflammation and fibrosis in a spontaneous model of type 2 diabetes, the GK rat. Diabetes 55:1625-1633. doi:10.2337/ db05-1526

52. Hoque R, Malik AF, Gorelick F, Mehal WZ (2012) Sterile inflammatory response in acute pancreatitis. Pancreas 41:353-357. doi: 10.1097/MPA.0b013e3182321500

53. Huang W, Wang G, Delaspre F, Vitery Mdel C, Beer RL, Parsons MJ (2014) Retinoic acid plays an evolutionarily conserved and biphasic role in pancreas development. Dev Biol 394:83-93

54. Hwang RF, Moore T, Arumugam T, Ramachandran V, Amos KD, Rivera A, Ji B, Evans DB, Logsdon CD (2008) Cancer-associated stromal fibroblasts promote pancreatic tumor progression. Cancer Res 68:918-926

55. Ikejiri N (1990) The vitamin A-storing cells in the human and rat pancreas. Kurume Med J 37:67-81

56. Iwatsuki N, Petersen $\mathrm{OH}$ (1978) Electrical coupling and uncoupling of exocrine acinar cells. J Cell Biol 79:533-545

57. Iwatsuki N, Petersen OH (1979) Direct visualization of cell to cell coupling: transfer of fluorescent probes in living mammalian pancreatic acini. Pflugers Arch 380:277-281

58. Jakubowska MA, Ferdek PE, Gerasimenko OV, Gerasimenko JV, Petersen OH (2016) Nitric oxide signals are interlinked with calcium signals in normal pancreatic stellate cells upon oxidative stress and inflammation. Open Biol 6:160149. doi:10.1098/rsob. 160149

59. Jaster R (2004) Molecular regulation of pancreatic stellate cell function. Mol Cancer 3:26. doi:10.1186/1476-4598-3-26

60. Jaster R, Sparmann G, Emmrich J, Liebe S (2002) Extracellular signal regulated kinases are key mediators of mitogenic signals in rat pancreatic stellate cells. Gut 51:579-584

61. Jaster R, Lichte P, Fitzner B, Brock P, Glass A, Karopka T, Gierl L, Koczan D, Thiesen HJ, Sparmann G, Emmrich J, Liebe S (2005) Peroxisome proliferator-activated receptor gamma overexpression inhibits pro-fibrogenic activities of immortalised rat pancreatic stellate cells. J Cell Mol Med 9:670-682

62. Kane MA, Folias AE, Pingitore A, Perri M, Obrochta KM, Krois CR, Cione E, Ryu JY, Napoli JL (2010) Identification of 9-cisretinoic acid as a pancreas-specific autacoid that attenuates glucose-stimulated insulin secretion. Proc Natl Acad Sci U S A 107:21884-21889

63. Kang Q, Chen A (2009) Curcumin eliminates oxidized LDL roles in activating hepatic stellate cells by suppressing gene expression of lectin-like oxidized LDL receptor-1. Lab Investig 89:12751290. doi:10.1038/labinvest.2009.93

64. Kemeny LV, Schnur A, Czepan M, Rakonczay Z Jr, Gal E, Lonovics J, Lazar G, Simonka Z, Venglovecz V, Maleth J, Judak L, Nemeth IB, Szabo K, Almassy J, Virag L, Geisz A, Tiszlavicz L, Yule DI, Wittmann T, Varro A, Hegyi P (2013) Na+/Ca2+ exchangers regulate the migration and proliferation of human gastric myofibroblasts. Am J Physiol Gastrointest Liver Physiol 305: G552-G563. doi:10.1152/ajpgi.00394.2012

65. Kim N, Yoo W, Lee J, Kim H, Lee H, Kim YS, Kim DU, Oh J (2009) Formation of vitamin a lipid droplets in pancreatic stellate cells requires albumin. Gut 58:1382-1390. doi:10.1136/gut.2008. 170233

66. Knook DL, Seffelaar AM, de Leeuw AM (1982) Fat-storing cells of the rat liver. Their isolation and purification. Exp Cell Res 139: 468-471

67. Konturek SJ, Bilski J, Konturek PK, Cieszkowski M, Pawlik W (1993) Role of endogenous nitric oxide in the control of canine pancreatic secretion and blood flow. Gastroenterology 104:896902

68. Kunzli BM, Berberat PO, Giese T, Csizmadia E, Kaczmarek E, Baker C, Halaceli I, Buchler MW, Friess H, Robson SC (2007) Upregulation of CD39/NTPDases and P2 receptors in human pancreatic disease. Am J Physiol Gastrointest Liver Physiol 292: G223-G230. doi:10.1152/ajpgi.00259.2006

69. Lerch MM, Gorelick FS (2013) Models of acute and chronic pancreatitis. Gastroenterology 144:1180-1193

70. Luttenberger T, Schmid-Kotsas A, Menke A, Siech M, Beger H, Adler G, Grunert A, Bachem MG (2000) Platelet-derived growth factors stimulate proliferation and extracellular matrix synthesis of pancreatic stellate cells: implications in pathogenesis of pancreas fibrosis. Lab Investig 80:47-55

71. Majumder S, Chari ST (2016) Chronic pancreatitis. Lancet 387: 1957-1966. doi:10.1016/S0140-6736(16)00097-0

72. Mantoni TS, Lunardi S, Al-Assar O, Masamune A, Brunner TB (2011) Pancreatic stellate cells radioprotect pancreatic cancer cells through beta1-integrin signaling. Cancer Res 71:3453-3458

73. Marrache F, Pendyala S, Bhagat G, Betz KS, Song Z, Wang TC (2008) Role of bone marrow-derived cells in experimental chronic pancreatitis. Gut 57:1113-1120. doi:10.1136/gut.2007.143271

74. Martin M, Gallego-Llamas J, Ribes V, Kedinger M, Niederreither K, Chambon P, Dolle P, Gradwohl G (2005) Dorsal pancreas agenesis in retinoic acid-deficient Raldh2 mutant mice. Dev Biol 284:399-411

75. Masamune A, Shimosegawa T (2009) Signal transduction in pancreatic stellate cells. J Gastroenterol 44:249-260. doi:10.1007/ s00535-009-0013-2 
76. Masamune A, Kikuta K, Satoh M, Sakai Y, Satoh A, Shimosegawa T (2002) Ligands of peroxisome proliferatoractivated receptor-gamma block activation of pancreatic stellate cells. J Biol Chem 277:141-147. doi:10.1074/jbc.M107582200

77. Masamune A, Sakai Y, Kikuta K, Satoh M, Satoh A, Shimosegawa T (2002) Activated rat pancreatic stellate cells express intercellular adhesion molecule-1 (ICAM-1) in vitro. Pancreas 25:78-85

78. Masamune A, Satoh M, Kikuta K, Sakai Y, Satoh A, Shimosegawa $T$ (2003) Inhibition of p38 mitogen-activated protein kinase blocks activation of rat pancreatic stellate cells. J Pharmacol Exp Ther 304:8-14. doi:10.1124/jpet.102.040287

79. Masamune A, Satoh M, Kikuta K, Suzuki N, Shimosegawa T (2005) Endothelin-1 stimulates contraction and migration of rat pancreatic stellate cells. World J Gastroenterol 11:6144-6151

80. Masamune A, Kikuta K, Watanabe T, Satoh K, Hirota M, Shimosegawa T (2008) Hypoxia stimulates pancreatic stellate cells to induce fibrosis and angiogenesis in pancreatic cancer. Am J Physiol Gastrointest Liver Physiol 295:G709-G717

81. Masamune A, Kikuta K, Watanabe T, Satoh K, Satoh A, Shimosegawa T (2008) Pancreatic stellate cells express toll-like receptors. J Gastroenterol 43:352-362

82. McCarroll JA, Phillips PA, Santucci N, Pirola RC, Wilson JS, Apte MV (2006) Vitamin A inhibits pancreatic stellate cell activation: implications for treatment of pancreatic fibrosis. Gut 55: 79-89. doi:10.1136/gut.2005.064543

83. Mews P, Phillips P, Fahmy R, Korsten M, Pirola R, Wilson J, Apte M (2002) Pancreatic stellate cells respond to inflammatory cytokines: potential role in chronic pancreatitis. Gut 50:535-541

84. Muerkoster S, Wegehenkel K, Arlt A, Witt M, Sipos B, Kruse ML, Sebens T, Kloppel G, Kalthoff H, Folsch UR, Schafer H (2004) Tumor stroma interactions induce chemoresistance in pancreatic ductal carcinoma cells involving increased secretion and paracrine effects of nitric oxide and interleukin-1beta. Cancer Res 64:13311337

85. Neuschwander-Tetri BA, Bridle KR, Wells LD, Marcu M, Ramm GA (2000) Repetitive acute pancreatic injury in the mouse induces procollagen alpha1(I) expression colocalized to pancreatic stellate cells. Lab Investig 80:143-150

86. Ozdemir BC, Pentcheva-Hoang T, Carstens JL, Zheng X, Wu CC, Simpson TR, Laklai H, Sugimoto H, Kahlert C, Novitskiy SV, De Jesus-Acosta A, Sharma P, Heidari P, Mahmood U, Chin L, Moses HL, Weaver VM, Maitra A, Allison JP, LeBleu VS, Kalluri R (2014) Depletion of carcinoma-associated fibroblasts and fibrosis induces immunosuppression and accelerates pancreas cancer with reduced survival. Cancer Cell 25:719-734. doi:10.1016/j.ccr. 2014.04.005

87. Pandol SJ, Raraty M (2007) Pathobiology of alcoholic pancreatitis. Pancreatology 7:105-114. doi:10.1159/000104235

88. Pareja E, Artigues E, Mir J, Fabra R, Martinez V, Vazquez A, Trullenque R (2003) Main pancreatic duct: morphlogy after acute biliary pancreatitis with magnetic resonance cholangiopancreatography after secretin stimulation. Rev Esp Enferm Dig 95(395-400):389-394

89. Park YM (2014) CD36, a scavenger receptor implicated in atherosclerosis. Exp Mol Med 46:e99. doi:10.1038/emm.2014.38

90. Patel AG, Toyama MT, Nguyen TN, Cohen GA, Ignarro LJ, Reber HA, Ashley SW (1995) Role of nitric oxide in the relationship of pancreatic blood flow and exocrine secretion in cats. Gastroenterology 108:1215-1220

91. Petersen OH (1992) Stimulus-secretion coupling: cytoplasmic calcium signals and the control of ion channels in exocrine acinar cells. J Physiol 448:1-51

92. Petersen $\mathrm{OH}$, Sutton $\mathrm{R}$ (2006) $\mathrm{Ca}^{2+}$ signalling and pancreatitis: effects of alcohol, bile and coffee. Trends Pharmacol Sci 27: 113-120. doi:10.1016/j.tips.2005.12.006
93. Petersen OH, Tepikin AV (2008) Polarized calcium signaling in exocrine gland cells. Annu Rev Physiol 70:273-299. doi:10.1146/ annurev.physiol.70.113006.100618

94. Petersen OH, Tepikin AV, Gerasimenko JV, Gerasimenko OV, Sutton R, Criddle DN (2009) Fatty acids, alcohol and fatty acid ethyl esters: toxic $\mathrm{Ca}^{2+}$ signal generation and pancreatitis. Cell Calcium 45:634-642. doi:10.1016/j.ceca.2009.02.005

95. Phillips PA, McCarroll JA, Park S, Wu MJ, Pirola R, Korsten M, Wilson JS, Apte MV (2003) Rat pancreatic stellate cells secrete matrix metalloproteinases: implications for extracellular matrix turnover. Gut 52:275-282

96. Phillips PA, Yang L, Shulkes A, Vonlaufen A, Poljak A, Bustamante S, Warren A, Xu Z, Guilhaus M, Pirola R, Apte MV, Wilson JS (2010) Pancreatic stellate cells produce acetylcholine and may play a role in pancreatic exocrine secretion. Proc Natl Acad Sci U S A 107:17397-17402. doi:10.1073/pnas. 1000359107

97. Rhinn M, Dolle P (2012) Retinoic acid signalling during development. Development 139:843-858

98. Rosewicz S, Stier U, Brembeck F, Kaiser A, Papadimitriou CA, Berdel WE, Wiedenmann B, Riecken EO (1995) Retinoids: effects on growth, differentiation, and nuclear receptor expression in human pancreatic carcinoma cell lines. Gastroenterology 109: 1646-1660

99. Saotome T, Inoue H, Fujimiya M, Fujiyama Y, Bamba T (1997) Morphological and immunocytochemical identification of periacinar fibroblast-like cells derived from human pancreatic acini. Pancreas 14:373-382

100. Sarper M, Cortes E, Lieberthal TJ, Del Rio HA (2016) ATRA modulates mechanical activation of TGF-beta by pancreatic stellate cells. Sci Rep 6:27639. doi:10.1038/srep27639

101. Sato K, Hirano M, Nakashima T (2001) Stellate cells in the human vocal fold. Ann Otol Rhinol Laryngol 110:319-325

102. Scarlett CJ, Colvin EK, Pinese M, Chang DK, Morey AL, Musgrove EA, Pajic M, Apte M, Henshall SM, Sutherland RL, Kench JG, Biankin AV (2011) Recruitment and activation of pancreatic stellate cells from the bone marrow in pancreatic cancer: a model of tumor-host interaction. PLoS One 6:e26088. doi:10. 1371/journal.pone.0026088

103. Schaefer L (2014) Complexity of danger: the diverse nature of damage-associated molecular patterns. J Biol Chem 289:3523735245

104. Schmitt-Graff A, Kruger S, Bochard F, Gabbiani G, Denk H (1991) Modulation of alpha smooth muscle actin and desmin expression in perisinusoidal cells of normal and diseased human livers. Am J Pathol 138:1233-1242

105. Schneider E, Schmid-Kotsas A, Zhao J, Weidenbach H, Schmid RM, Menke A, Adler G, Waltenberger J, Grunert A, Bachem MG (2001) Identification of mediators stimulating proliferation and matrix synthesis of rat pancreatic stellate cells. Am J Physiol Cell Physiol 281:C532-C543

106. Schneiderhan W, Schmid-Kotsas A, Zhao J, Grunert A, Nussler A, Weidenbach H, Menke A, Schmid RM, Adler G, Bachem MG (2001) Oxidized low-density lipoproteins bind to the scavenger receptor, CD36, of hepatic stellate cells and stimulate extracellular matrix synthesis. Hepatology 34:729-737. doi:10.1053/jhep. 2001.27828

107. Schneiderhan W, Diaz F, Fundel M, Zhou S, Siech M, Hasel C, Moller P, Gschwend JE, Seufferlein T, Gress T, Adler G, Bachem MG (2007) Pancreatic stellate cells are an important source of MMP-2 in human pancreatic cancer and accelerate tumor progression in a murine xenograft model and CAM assay. J Cell Sci 120: 512-519

108. Shields MA, Dangi-Garimella S, Redig AJ, Munshi HG (2012) Biochemical role of the collagen-rich tumour microenvironment 
in pancreatic cancer progression. Biochem J 441:541-552. doi:10. 1042/BJ20111240

109. Shimada M, Andoh A, Hata K, Tasaki K, Araki Y, Fujiyama Y, Bamba T (2002) IL-6 secretion by human pancreatic periacinar myofibroblasts in response to inflammatory mediators. J Immunol 168:861-868

110. Shimizu K, Kobayashi M, Tahara J, Shiratori K (2005) Cytokines and peroxisome proliferator-activated receptor gamma ligand regulate phagocytosis by pancreatic stellate cells. Gastroenterology 128:2105-2118

111. Sies H (2015) Oxidative stress: a concept in redox biology and medicine. Redox Biol 4:180-183

112. Sousa CM, Biancur DE, Wang X, Halbrook CJ, Sherman MH, Zhang L, Kremer D, Hwang RF, Witkiewicz AK, Ying H, Asara JM, Evans RM, Cantley LC, Lyssiotis CA, Kimmelman AC (2016) Pancreatic stellate cells support tumour metabolism through autophagic alanine secretion. Nature 536:479-483

113. Sparmann G, Hohenadl C, Tornoe J, Jaster R, Fitzner B, Koczan D, Thiesen HJ, Glass A, Winder D, Liebe S, Emmrich J (2004) Generation and characterization of immortalized rat pancreatic stellate cells. Am J Physiol Gastrointest Liver Physiol 287: G211-G219. doi:10.1152/ajpgi.00347.2003

114. Sparmann G, Kruse ML, Hofmeister-Mielke N, Koczan D, Jaster R, Liebe S, Wolff D, Emmrich J (2010) Bone marrow-derived pancreatic stellate cells in rats. Cell Res 20:288-298. doi:10. 1038/cr.2010.10

115. Storck H, Hild B, Schimmelpfennig S, Sargin S, Nielsen N, Zaccagnino A, Budde T, Novak I, Kalthoff H, Schwab A (2016) Ion channels in control of pancreatic stellate cell migration. Oncotarget. doi:10.18632/oncotarget.13647

116. Tahara H, Sato K, Yamazaki Y, Ohyama T, Horiguchi N, Hashizume H, Kakizaki S, Takagi H, Ozaki I, Arai H, Hirato J, Jesenofsky R, Masamune A, Mori M (2013) Transforming growth factor-alpha activates pancreatic stellate cells and may be involved in matrix metalloproteinase-1 upregulation. Lab Investig 93:720-732. doi:10.1038/labinvest.2013.59

117. Takaya H, Andoh A, Shimada M, Hata K, Fujiyama Y, Bamba T (2000) The expression of chemokine genes correlates with nuclear factor-kappaB activation in human pancreatic cancer cell lines. Pancreas 21:32-40

118. Tulachan SS, Doi R, Kawaguchi Y, Tsuji S, Nakajima S, Masui T, Koizumi M, Toyoda E, Mori T, Ito D, Kami K, Fujimoto K, Imamura M (2003) All-trans retinoic acid induces differentiation of ducts and endocrine cells by mesenchymal/epithelial interactions in embryonic pancreas. Diabetes 52:76-84

119. Venglovecz V, Rakonczay Z Jr, Ozsvari B, Takacs T, Lonovics J, Varro A, Gray MA, Argent BE, Hegyi P (2008) Effects of bile acids on pancreatic ductal bicarbonate secretion in guinea pig. Gut 57:1102-1112. doi:10.1136/gut.2007.134361

120. Vincent A, Herman J, Schulick R, Hruban RH, Goggins M (2011) Pancreatic cancer. Lancet 378:607-620. doi:10.1016/S01406736(10)62307-0

121. Vogelmann R, Ruf D, Wagner M, Adler G, Menke A (2001) Effects of fibrogenic mediators on the development of pancreatic fibrosis in a TGF-beta1 transgenic mouse model. Am J Physiol Gastrointest Liver Physiol 280:G164-G172

122. Vonlaufen A, Joshi S, Qu C, Phillips PA, Xu Z, Parker NR, Toi CS, Pirola RC, Wilson JS, Goldstein D, Apte MV (2008)
Pancreatic stellate cells: partners in crime with pancreatic cancer cells. Cancer Res 68:2085-2093

123. Vonlaufen A, Phillips PA, Xu Z, Zhang X, Yang L, Pirola RC, Wilson JS, Apte MV (2011) Withdrawal of alcohol promotes regression while continued alcohol intake promotes persistence of LPS-induced pancreatic injury in alcohol-fed rats. Gut 60:238 246. doi:10.1136/gut.2010.211250

124. Warshaw AL, Fernandez-del Castillo C (1992) Pancreatic carcinoma. N Engl J Med 326:455-465. doi:10.1056/ NEJM199202133260706

125. Watanabe T, Masamune A, Kikuta K, Hirota M, Kume K, Satoh K, Shimosegawa T (2009) Bone marrow contributes to the population of pancreatic stellate cells in mice. Am J Physiol Gastrointest Liver Physiol 297:G1138-G1146. doi:10.1152/ ajpgi.00123.2009

126. Watari N, Hotta Y, Mabuchi Y (1982) Morphological studies on a vitamin A-storing cell and its complex with macrophage observed in mouse pancreatic tissues following excess vitamin A administration. Okajimas Folia Anat Jpn 58:837-858

127. Wen L, Voronina S, Javed MA, Szatmary P, Latawiec D, Chvanov M, Collier D, Huang W, Barret J, Begg M, Stauderman K, Roos J, Grigoryev S, Ramos S, Rogers E, Whitten J, Velicelebi G, Dunn M, Tepikin AV, Criddle DN, Sutton R (2015) Inhibitors of ORAI1 prevent cytosolic calcium-associated injury of human pancreatic acinar cells and acute pancreatitis in 3 mouse models. Gastroenterology 149:481-492

128. Won JH, Zhang Y, Ji B, Logsdon CD, Yule DI (2011) Phenotypic changes in mouse pancreatic stellate cell $\mathrm{Ca}^{2+}$ signaling events following activation in culture and in a disease model of pancreatitis. Mol Biol Cell 22:421-436. doi:10.1091/mbc.E10-10-0807

129. Wynn TA, Ramalingam TR (2012) Mechanisms of fibrosis: therapeutic translation for fibrotic disease. Nat Med 18:1028-1040. doi: $10.1038 / \mathrm{nm} .2807$

130. Xiao W, Jiang W, Shen J, Yin G, Fan Y, Wu D, Qiu L, Yu G, Xing M, Hu G, Wang X, Wan R (2015) Retinoic acid ameliorates pancreatic fibrosis and inhibits the activation of pancreatic stellate cells in mice with experimental chronic pancreatitis via suppressing the Wnt/beta-catenin signaling pathway. PLoS One 10: e0141462. doi:10.1371/journal.pone.0141462

131. Xu Z, Vonlaufen A, Phillips PA, Fiala-Beer E, Zhang X, Yang L, Biankin AV, Goldstein D, Pirola RC, Wilson JS, Apte MV (2010) Role of pancreatic stellate cells in pancreatic cancer metastasis. Am J Pathol 177:2585-2596

132. Yokoi Y, Namihisa T, Kuroda H, Komatsu I, Miyazaki A, Watanabe S, Usui K (1984) Immunocytochemical detection of desmin in fat-storing cells (Ito cells). Hepatology 4:709-714

133. Young MJ, Wu YH, Chiu WT, Weng TY, Huang YF, Chou CY (2015) All-trans retinoic acid downregulates ALDH1-mediated stemness and inhibits tumour formation in ovarian cancer cells. Carcinogenesis 36:498-507. doi:10.1093/carcin/bgv018

134. Zha M, Li F, Xu W, Chen B, Sun Z (2014) Isolation and characterization of islet stellate cells in rat. Islets 6:e28701. doi:10.4161/ isl.28701

135. Zhang LP, Ma F, Abshire SM, Westlund KN (2013) Prolonged high fat/alcohol exposure increases TRPV4 and its functional responses in pancreatic stellate cells. Am J Physiol Regul Integr Comp Physiol 304:R702-R711. doi:10.1152/ajpregu.00296.2012

136. Zhao L, Burt AD (2007) The diffuse stellate cell system. J Mol Histol 38:53-64. doi:10.1007/s10735-007-9078-5 